Camacho, T.F.; Oliveira, M.T.C. Parque Estadual Itinguçu, Peruíbe (SP): diagnóstico preliminar das condições de uso público. Anais do VIII Congresso Nacional de Ecoturismo e do IV Encontro Interdisciplinar de Ecoturismo em Unidades de Conservação. Revista Brasileira de Ecoturismo, São Paulo, v.4, n.4, 2011, p. 560.

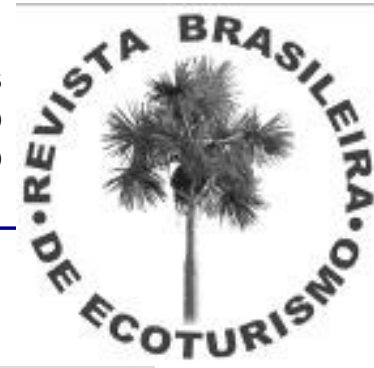

\title{
PARQUE ESTADUAL ITINGUCU, PERUÍBE (SP): DIAGNÓSTICO PRELIMINAR DAS CONDIÇÕES DE USO PÚBLICO
}

\section{Tamiris Filipavicius Camacho, Marcelo Teixeira Cesar de Oliveira*}

*Instituto Ipá Ti-uá de Meio Ambiente, Cultura e Sociedade

E-mails: tfctamiris@hotmail.com, marcelotco@ipatiua.com.br,

O Mosaico de Unidades de Conservação (UC) Juréia-Itatins é formado por quatro UCs de proteção integral: Estação Ecológica Juréia-Itatins (EEJI), Parque Estadual Itinguçu (PEIT), do Prelado (PEP) e Refúgio de Vida Silvestre (RVS), além de duas UCs de uso sustentável: Reservas de Desenvolvimento Sustentável da Barra do Una (RDSBU) e do Despraiado (RDSD). Com mais de 110 mil ha está situado na litoral sul do Estado de São Paulo, nos municípios de Iguape, Itariri, Miracatu, Pedro de Toledo e Peruíbe. Apresenta os seguintes biomas: brejos, lagunas, dunas, restingas arbóreas, arbustivas e herbáceas, manguezais e Mata Atlântica. A área escolhida para o estudo foi o Parque Estadual do Itinguçu, localizado em Peruíbe, São Paulo, possuindo aproximadamente 8.400 ha e localizada nas coordenadas $24^{\circ} 18^{\prime}$ a $24^{\circ} 37^{\prime} \mathrm{S}$ e $47^{\circ} 00^{\prime}$ a $47^{\circ} 31^{\prime} \mathrm{W}$. O PEIT é dividido em dois núcleos: o Núcleo Itinguçu, que é a unidade de conservação constituinte do mosaico que mais recebe a visitação pública, e o Núcleo do Arpoador, aberto apenas para visitas com cunho educativo ou para pesquisas científicas. $O$ trabalho objetivou avaliar, de forma preliminar, a infra-estrutura para uso público, suas condições e adequação, e a qualidade das atividades realizadas com os visitantes. $O$ trabalho foi realizado no segundo semestre de 2008 e o registro da visita diagnóstica foi elaborado através do levantamento por imagens fotográficas e anotações de campo com os relatos de funcionários do parque e moradores locais. A pesquisa foi complementada através de leitura de livros, periódicos, documentos e da legislação, além de outras informações obtidas pela internet. Verificou-se que o acesso ao Parque Estadual do Itinguçu é fácil pela Estrada do Guaraú. Chega-se a região através da Rodovia Pedro Taques (SP-55) e pelas Rodovias Regis Bittencourt (BR-160) e Rodovia Prefeito Cassimiro Teixeira (SP-222). Nas instalações administrativas encontram-se: um pequeno auditório que com capacidade para aproximadamente 30 pessoas com equipamentos de multimídia, além de laboratório, loja de artesanato e área reservada para museu. $\mathrm{Na}$ área do Parque encontra-se estacionamento para visitantes, cestos de coleta seletiva, quiosques para alimentação, vários sanitários (masculino, feminino e para pessoas com deficiência) com rampas de acesso para portadoras de deficiência. Os visitantes não necessitam de autorização para circular na área, exceto grupos que excedam a capacidade de 20 pessoas (excursões organizadas) que é exigido o acompanhamento de um monitor ambiental cadastrado na PEIT. Os percursos de trilhas abertos ao público cortam áreas de Mata Atlântica. Dentre eles estão às trilhas do Vilão, das praias e das cachoeiras, como a praia da Barra do Una, as cachoeiras do Paraíso, das Antas e Perequê, sendo todos identificados com placas informativas. O Parque possui infra-estrutura suficiente para realização de programas de Educação Ambiental (E.A), mas tem uma equipe pequena de monitores para atender a grande demanda de visitantes e assim realizar programas educativos. Além disso, no parque existe um viveiro com mudas de espécies nativas, mas está desativado. Poderia ser utilizado como ferramenta de ensino nos programas de E.A.

Palavras-Chave: Juréia-Itatins; Núcleo Itinguçu; Uso Público. 